\title{
POTENSI EKONOMI PADA KOLONG BEKAS PENAMBANGAN TIMAH DI KABUPATEN BANGKA, PROVINSI BANGKA BELITUNG
}

\author{
Oleh: Oot Hotimah*
}

\begin{abstract}
The development of the tin mining industry in Bangka Bangka Belitung has contributed very significantly to the economy of communities in the region. But on the other hand, these activities also have a negative effect in the form of reduced mangrove forests, destruction of soil, polluted water sources, as well as the emergence of pits (pit) excavated and others. So far under the utilization of tin in Bangka Island is not optimal. Economically, the potential pit can be used as a source of raw water, aquaculture, or recreational water. This can be done through environmental reclamation. Technically goal of rehabilitation is to restore the soil conditions for stable and not prone to erosion. From the economical and aesthetic aspects of land, soil conditions improved so that the value or economic potential can be restored at least its original state. From the aspect of the ecosystem, ecosystem condition to attempt the return of the original ecosystem.
\end{abstract}

Key Words: Tin mining, environment, rehabilitation.

\section{Pendahuluan}

Ekonomi lingkungan adalah ilmu yang mempelajari kegiatan manusia dalam memanfaatkan lingkungan sedemikian rupa sehingga fungsi dan peran lingkungan dapat dipertahankan atau bahkan dapat ditingkatkan dalam penggunaannya untuk jangka panjang. Sesungguhnya fungsi dan peranan lingkungan yang utama adalah sebagai penunjang kehidupan (life support system) dengan menyediakan sumberdaya alam sebagai bahan mentah untuk diolah menjadi barang jadi atau untuk langsung dikonsumsi, sebagai assimilator yang mengolah limbah secara alami dan sebagai sumber kesenangan (amenity) (Suparmoko, 2011).

\footnotetext{
* Dosen Program Studi Pendidikan Geografi Fakultas Ilmu Sosial Universitas Negeri Jakarta
}

Seiring dengan peranan lingkungan yang menurun dari waktu ke waktu karena semakin meningkatnya pembangunan demi meningkatkan kesejahteraan manusia, industri pertambangan dalam sejarah perkembangannya merupakan lapangan usaha yang juga sudah ada pada zaman nenek moyang bangsa Indonesia. Industri pertambangan dilakukan secara tradisional sejak beberapa abad yang lalu. Pada masa penjajahan Belanda tahun 1949 kegiatan penambangan timah dilakukan komersial di Pulau Bangka-Belitung tahun 1850.

Saat ini industri pertambangan nasional sudah berkembang setara dengan industri pertambangan multinasional dengan menggunakan metoda dan teknologi maju mulai dari kegiatan eksplorasi sampai 
dengan pengolahan. Tujuannya adalah untuk meningkatkan perekonomian daerah bahkan nasional dengan memegang prinsip penambangan berwawasan lingkungan yang mengoptimalkan pemanfaatan sumberdaya mineral bagi kesejahteraan rakyat serta dalam pelaksanaannya memenuhi peraturan perundangan yang mencakup teknologi, keselamatan kerja, pelestarian lingkungan secara terpadu dengan sektor-sektor lain.

Tolok ukur keberhasilan dari industri pertambangan adalah bila aspek perekonomian dan sosial budaya berkembang dengan baik atau disebut dampak non teknis serta dapat dikendalikannya penurunan kualitas alam dengan penataan lingkungan yang baik atau dapat disebut dampak teknis di wilayah sekitar industri pertambangan. Bahkan keberhasilan tersebut dicirikan dengan tetap berjalannya kegiatan perekonomian atau lebih meningkat serta membaiknya kesejahteraan masyarakat di wilayah industri pertambangan pada saat sumberdaya mineral sudah habis, sehingga akan tercipta pembangunan berkelanjutan di mana wilayah tersebut akan tetap tumbuh dan berkembang. Berdasarkan uraian tersebut artikel ini akan membahas secara ringkas bagaimana dimensi usaha pertambangan di Provinsi Bangka Belitung, khususnya dalam pemanfaatan kolong bekas pertambangan timah.
Perkembangan Industri Pertambangan Timah

Perkembangan

industri

pertambangan timah mengalami perkembangan penting, khususnya pada dekade 1970-an, ketika pemerintah membuka kesempatan bagi pihak asing untuk menanamkan modalnya di bidang pertambangan, yakni Tambang Karya (TK) selain PT. Timah Tbk sebagai perusahaan nasional yang mengelola tambang timah. Tambang Karya ini dimiliki oleh pihak swasta Indonesia dan asing yang telah mengadakan perjanjian kontrak dengan pemerintah (kontrak karya) dengan memanfaatkan para penambang rakyat. Tambang Karya berkontribusi dalam meningkatkan kapasitas produksi PT. Timah Tbk karena menambang dalam wilayah Kuasa Pertambangan (KP) PT. Timah Tbk. Umumnya aktivitas penambangan Tambang Karya dilakukan pada wilayah-wilayah bekas "tambang dalam" yang sudah ditinggalkan Belanda, adapun PT. Timah tetap berfungsi sebagai pengumpul timah yang dihasilkan oleh Tambang Karya, sedangkan jenis timah yang ditambang adalah timah primer.

Kegiatan penambangan timah pasca tahun 90-an merujuk pada Surat Keputusan Menteri Perindustrian dan Perdagangan (Kepmenperindag) No.558 Tahun 1998 dan No.146 Tahun 1999 yang menyatakan timah sebagai komoditas bebas ekspor. Peraturan 
ini menegaskan bahwa timah bukan lagi sebagai bahan galian strategis, dan penduduk setempat menginterpretasikan bahwa timah dapat ditambang secara "legal" dan bebas tanpa perlu mengurus perijinan tambang yang lazim dilakukan oleh PT. Timah Tbk dahulu. Adanya Kepmenperindag di atas menjadi alasan "terkuat" masyarakat untuk melakukan kegitan penambangan timah, sehingga pertambangan timah rakyat semakin banyak jumlahnya.

\section{Menjelang akhir tahun 1998,} teknologi pertambangan dimanfaatkan oleh para penambang rakyat. Penambang menggunakan alat-alat eksplorasi tambang yang dapat meningkatkan hasil produksi bijih timah, eksplorasi tambang yang tadinya hanya di wilayah bekas tambang mulai merambah pada wilayah lain yang seharusnya tidak ditambang, misalnya wilayah tambang yang telah direklamasi, bahkan ada penambang yang berani melakukan penambangan di areal hutan lindung dan hutan lindung pantai.

Maraknya tambang inkonvensional atau lebih dikenal sebagai TI, diawali dengan diterbitkannya SK Menperindag Nomor. 146/MPP/Kep/4/1999 tanggal 22 April 1999 bahwa timah diketegorikan sebagai barang bebas (tidak diawasi) dan pencabutan status timah sebagai komoditas strategis, sehingga tidak dimonopoli lagi oleh satu BUMN dan dapat dieskpor secara bebas oleh siapa pun. Maraknya kegiatan TI tersebut pada akhirnya tentu saja berdampak pada lingkungan. Sebagai upaya mengantisipasi tingkat kerusakan lingkungan yang semakin parah diperlukan payung hukum yang jelas sebagai acuan dalam pelaksanaan kegiatan penambangan. Maka pemerintah Kabupaten Bangka dengan persetujuan DPRD mengeluarkan beberapa kebijakan diantaranya:

1. Peraturan Daerah No. 6 Tahun 2001 Tentang Pengelolaan Pertambangan Umum.

2. Peraturan Daerah No. 20 Tahun 2001 Tentang Penetapan dan Pengaturan Tatalaksana Perdagangan Barang Strategis.

3. Peraturan Daerah No. 21 Tahun 2001 Tentang Pajak Pertambangan Umum dan Mineral Ikutan Lainnya.

Disebut dengan tambang inkonvensional (TI) karena metode penambangannya tidak seperti penambangan terbuka (open mining) namun hanya menggunakan mesin penyedot tanah dan air dengan kebutuhan modal hanya berkisar Rp 15 juta. Menurut sumber BPS Kabupaten Bangka Tahun 2003, Tambang Inkonvensional (TI) memberikan kontribusi yang sangat signifikan terhadap perekonomian masyarakat di wilayah Provinsi Kepulauan Bangka Belitung, dimana selama tahun 
$2000-2002$ terdapat 6.000 unit tambang inkonvensional. Rata-rata 1 (satu) unit tambang inkonvensional menghasilkan 10 ribu ton pasir timah, maka jumlah produksi bijih timah dari TI mencapai 60.000 ton per tahun. Jumlah ini lebih besar dari produksi PT Tambang Timah dan PT. Koba Tin yang hanya mampu memproduksi sekitar 45.000 ton per tahun. Besarnya jumlah produksi TI yang pada gilirannya akan masuk ke pasar internasional tersebut dapat mempengaruhi stok logam timah dunia dan selanjutnya membahayakan kestabilan harga bijih timah dunia.

Menurut survei yang dilakukan oleh Dinas Pertambangan dan Energi Kabupaten Bangka, pada tahun 2006 total ekspor logam timah Indonesia diperkirakan mencapai 123.500 ton. Dari jumlah tersebut, kontribusi PT. Timah sebesar 43.000 ton, PT. Koba Tin 20.500 ton, dan sisanya dari smelter swasta ilegal sebesar 60.000 ton atau mencapai hampir sepertiga total produksi timah dunia.

Maraknya industri TI, telah menciptakan keuntungan bagi perekonomian Bangka Belitung dengan menggeliatnya sektor pertambangan dan penyerapan tenaga kerja, namun juga menimbulkan berbagai masalah yang merugikan sektor ekonomi lain, khususnya pertanian dan kerusakan lingkungan.
Penambangan timah di Pulau Bangka dilaksanakan oleh perusahaan tambang Badan Usaha Milik Negara (BUMN) yaitu PT. Timah Tbk yang memiliki Kuasa Penambangan (KP) seluas 473.800,06 Ha atau 27,56\% dari luas Pulau Bangka yang tersebar hampir di seluruh wilayah kecamatan. Kuasa Penambangan PT. Timah Tbk ini dilakukan di darat dengan luas 330.664,09 $\mathrm{Ha}$ dan di laut dengan luas 143.135,97 Нa (PT.Timah, 2010).

\section{Dampak Aktifitas Pertambangan}

Menurut BAPPEDA (Badan Perencanaan Pembangunan Daerah) Kabupaten Bangka (2010) penambangan timah di Pulau Bangka memberikan dampak sangat positif terhadap Pendapatan Domestik Regional Bruto (PDRB) per kapita sebesar Rp. 16.563.948 lebih tinggi daripada PDRB non-timah sebesar Rp. 12.765.712. Dampak positif lainnya adalah berupa penyerapan tenaga kerja, perdagangan, transportasi, dan pembangunan berbagai sarana pendukung.

Menurut Ria Delta (2007) penambangan timah di samping memberikan dampak positif terhadap perekonomian dan tenaga kerja di Kabupaten Bangka akan tetapi memberikan dampak negatif pula terhadap lingkungan. Penambangan timah memberikan dampak negatif berupa berkurangnya hutan bakau di 
Provinsi Babel sekitar 70\% dari $122.000 \mathrm{Ha}$ (Antara News, 2010).

Adanya aktivitas tambang rakyat di Pulau Bangka menyebabkan hancurnya tanah penutup yang hanyut dalam air, timbulnya genangan-genangan air, munculnya gundukan-gundukan tanah yang berupa pasir/kerikil dan berbahayanya ekosistem di sekitar penambangan. Selain itu, kondisi lingkungan pulau Bangka pada sebagian wilayah telah meninggalkan kolam-kolam air pada daerah bekas penambangan (kolong) yang semakin melebar pasca reklamasi PT. Timah di beberapa tampat, dengan adanya penambangan kembali di tempat tersebut.
Lubang tambang atau cekungan air merupakan dampak dari penambangan timah oleh penduduk Pulau Bangka disebut dengan nama Kolong.

Pada daerah tertentu, penambangan timah darat menghasilkan wilayah sungai besar yang disebut dengan kolong/danau. Kolong/danau itulah merupakan inti utama cara kerja penambangan darat, karena pola kerja penambangan darat sangat tergantung pada pengelolaan dan pemanfaatan sumber daya air dalam jumlah besar. Sehingga bila kita lihat dari udara, penambangan timah darat selalu menimbulkan genangan air dalam jumlah besar seperti danau dan tampak berlobang-lobang besar.

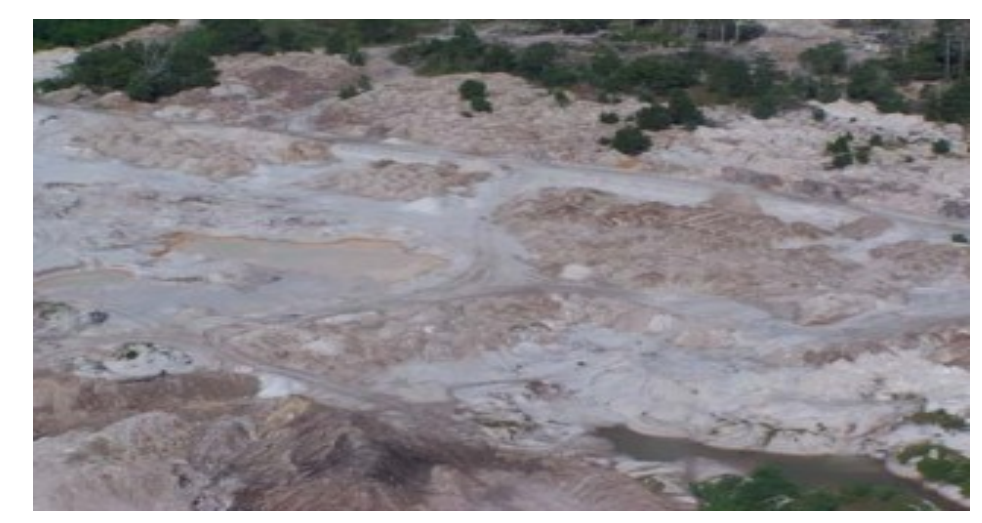

Gambar 3 Kolong Bekas penambangan di Bangka Belitung

Sumber : TRIBUNNEWS.COM/DOK (Jumat, 15 April 2011 21:08 WIB)

Lubang-lubang itu berpotensi menimbulkan dampak lingkungan jangka panjang, terutama berkaitan dengan kualitas dan kuantitas air. Air lubang tambang mengandung berbagai logam berat yang dapat merembes ke sistem air tanah dan dapat mencemari air tanah sekitar. Potensi bahaya akibat rembesan ke dalam air tanah seringkali tidak terpantau akibat lemahnya sistem pemantauan perusahaan-perusahaan pertambangan. Di Pulau Bangka dan Belitung banyak 
dijumpai lubang-lubang bekas galian tambang timah (kolong) yang berisi air bersifat asam dan sangat berbahaya. (Cynthia Henny, 2009).

\section{Potensi Kolong Bekas Tambang}

Keberadaan kolong bagi masyarakat dan Pemerintah Kabupaten Bangka bahwa kolong bekas galian penambangan timah masih belum optimal manfaatnya dan terus dilakukan penelitian ke arah pemberdayaan sumber daya kolong. Kolong di antaranya berfungsi sebagai tempat keperluan masyarakat sehari-hari (mandi dan cuci), mencuci lada putih dan sumber air PDAM (Perusahaan Daerah Air Minum). Peranan kolong bekas penambangan timah yang terdapat di Pulau Bangka cukup penting di antaranya merupakan cadangan air minum yang sangat berguna di musim kemarau oleh karena potensi sumber air tanah di Pulau Bangka tergolong kecil.

Kolong memiliki bentuk permukaan relatif sama dengan danau, perbedaan fisik kolong dan danau pada bagian tepi, di mana kolong memiliki tepi yang curam sebagai akibat pengerukan tanah yang dilakukan oleh perusahaan tambang, sehingga bentuk kolong cenderung berbentuk hiperbola. Kedalaman kolong yang dibentuk dari bekas tambang sangat bergantung pada kedalaman deposit timah yang ditambang di dalam tanah.
Sejauh ini pemanfaatan kolong timah di Pulau Bangka belum optimal. Sebagian besar hanya dibiarkan, secara ekologis kolong tersebut berfungsi sebagai kolam retensi dan water catchment area untuk menampung air hujan yang mengalir melalui aliran permukaan. Secara ekonomi, potensi kolong untuk dimanfaatkan sebagai sumber air baku, budidaya perairan, atau tempat rekreasi air belum banyak dilakukan, baik oleh perusahaan penambang maupun pemerintah. Demikian juga pemanfaatan lahan tailing yang semakin luas sampai saat ini hanya sebatas dihijaukan dengan tanaman-tanaman serbaguna (multipurpose tree species, MPTS), terutama akasia.

Reklamasi sebagai usaha untuk memperbaiki atau memulihkan kembali lahan yang rusak sebagai akibat kegiatan usaha pertambangan, agar dapat berfungsi secara optimal sesuai dengan kemampuannya (Direktorat Jenderal Rehabilitasi Hutan dan Lahan Departemen Kehutanan, 1997). Ruang lingkup reklamasi lahan meliputi: (1) pemulihan lahan bekas tambang untuk memperbaiki lahan yang terganggu ekologinya; (2) mempersiapkan lahan bekas tambang yang sudah diperbaiki ekologinya untuk pemanfaatan selanjutnya.

Sasaran akhir dari reklamasi tersebut adalah terciptanya lahan bekas tambang yang kondisinya aman, stabil dan tidak mudah tererosi sehingga dapat dimanfaatkan 
$90 \quad \mid \overline{\text { JURNAL ILMIAH MIMBAR DEMOKRASI }}$

kembali sesuai dengan peruntukannya (Direktorat Jenderal Mineral Batubara Dan Panas Bumi Departemen Energi dan Sumber Daya Mineral, 2006).

Menurut Sujitno (2007), arah dari upaya rehabilitasi lahan bekas tambang ditinjau dari aspek teknis adalah upaya untuk mengembalikan kondisi tanah agar stabil dan tidak rawan erosi. Dari aspek ekonomis dan estetika lahan, kondisi tanah diperbaiki agar nilai/potensi ekonomisnya dapat dikembalikan sekurang-kurangnya seperti keadaan semula. Dari aspek ekosistem, upaya pengembalian kondisi ekosistem ke ekosistem semula. Dalam hal ini revegetasi/reforestisasi adalah upaya yang dapat dinilai mencakup kepada kepentingan aspek-aspek tersebut. Reklamasi hampir selalu identik dengan revegetasi.

Revegetasi adalah usaha atau kegiatan penanaman kembali lahan bekas tambang (Direktorat Jenderal Rehabilitasi Hutan dan Lahan Departemen Kehutanan, 1997). Menurut Setiadi (2006), tujuan dari revegetasi akan mencakup re-establishment komunitas tumbuhan asli secara berkelanjutan untuk menahan erosi dan aliran permukaan, perbaikan biodiversitas dan pemulihan estetika lanskap. Pemulihan lanskap secara langsung menguntungkan bagi lingkungan melalui perbaikan habitat satwa liar, biodiversitas, produktivitas tanah dan kualitas air.
Landasan hukum utama kegiatan reklamasi adalah Undang-Undang Nomor 11 Tahun 1967 tentang KetentuanKetentuan Pokok Pertambangan. Pada Pasal 30 dari Undang-undang tersebut dinyatakan bahwa apabila selesai melakukan penambangan bahan galian pada suatu tempat pekerjaan, pemegang Kuasa Penambangan (KP) diwajibkan mengembalikan tanah sedemikian rupa sehingga tidak menimbulkan bahaya bagi masyarakat sekitarnya. Selanjutnya pada Peraturan Pemerintah Nomor 75 Tahun 2001, tentang Perubahan Kedua Atas PP No. 32/1969 tentang Pelaksanaan UU No 11 Tahun 1967 tentang Ketentuan-ketentuan Pokok Pertambangan Pasal 46 ayat (4) disebutkan bahwa sebelum meninggalkan bekas wilayah KP-nya, baik karena pembatalan maupun karena hal yang lain, pemegang KP harus terlebih dahulu melakukan usaha-usaha pengamanan terhadap benda-benda maupun bangunanbangunan dan keadaan tanah di sekitarnya yang dapat membahayakan keamanan umum.

Pada Pasal 46 ayat (5) disebutkan bahwa Menteri, Gubernur, Bupati/Walikota sesuai kewenangannya dapat menetapkan pengaturan keamanan bangunan dan pengendalian keadaan tanah yang harus dipenuhi dan ditaati oleh pemegang KP sebelum meninggalkan bekas wilayah KP. 
Peraturan pelaksanaan reklamasi lahan diatur dalam Keputusan Menteri Pertambangan dan Energi Nomor 1211.K/008/M.PE/1995 tentang Pencegahan dan Penanggulangan Perusakan dan Pencemaran Lingkungan pada Kegiatan Pertambangan Umum. Pada Pasal 12 ayat (1) reklamasi areal bekas tambang harus dilakukan secepatnya sesuai dengan rencana dan persyaratan yang telah ditetapkan, dan ayat (2), reklamasi dinyatakan selesai setelah disetujui oleh Dirjen. Pada Pasal 13 ayat (1), Kepala Teknik Tambang wajib menanami kembali daerah bekas tambang, termasuk daerah sekitar project area sesuai studi AMDAL yang bersangkutan.

\section{Pemanfaatan Kolong Pasca}

\section{Penambangan Timah}

Kolong bekas penambangan timah yang telah berusia lebih dari 20 tahun dan kolong itu penuh berisi air, maka air kolong tersebut aman untuk diminum dan ikan yang hidup pada kolong tersebut dapat dimakan karena kolong tersebut telah mengalami pengendapan mineral ikutan selain timah, yaitu eilmenite dan casiterite. Kedua jenis mineral tersebut tidak lagi mengeluarkan pancaran radiasi dari sifat radioaktif yang dimilikinya (Erisa Susanti, 2004).

Tabel 1. Karakter Umum Beberapa Kolong di Kabupaten Bangka

\begin{tabular}{|c|l|l|l|l|}
\hline No. & \multicolumn{1}{|c|}{ Lokasi Kolong } & $\begin{array}{c}\text { Luas } \\
\text { (Ha) }\end{array}$ & $\begin{array}{l}\text { Volume Air } \\
\text { (Juta Liter) }\end{array}$ & \multicolumn{1}{c|}{ Keterangan } \\
\hline 1 & Pemali & 20,0 & 10.000 & $\begin{array}{l}\text { Air jernih, batuan kongkresi Fe, } \\
\text { kuarsit, dan metamorfit. } \\
\text { Kolong Pemali berumur 40 tahun. } \\
\text { Kolong ini belum tercemar oleh } \\
\text { tailing, sehingga perlu dilestarikan } \\
\text { agar tetap dapat dipergunakan } \\
\text { sebagai bahan baku air minum }\end{array}$ \\
\hline 2 & Merawang & 10,0 & 5.000 & $\begin{array}{l}\text { Air keruh, batuan granit, kuarsit, dan } \\
\text { dipengaruhi oleh tambang } \\
\text { inkonvensional (T). } \\
\text { Di sekitar kolong ini sudah } \\
\text { dilakukan kegiatan reklamasi } \\
\text { dengan cara ditanami pohon akasia } \\
\text { dan pohon hutan lainnya. }\end{array}$ \\
\hline 3 & Belinyu & 12,0 & 420 & $\begin{array}{l}\text { Air keruh, berlumut, batuan granit, } \\
\text { dan tercemar oleh rendaman lada. } \\
\text { Pada saat ini, kolong ini merupakan } \\
\text { satu-satunya sumber baku air minum } \\
\text { untuk kota belinyu }\end{array}$ \\
\hline
\end{tabular}

Sumber : Team PPLH-Unsri, 2005. 
Sumberdaya air kolong di Kabupaten Bangka mempunyai potensi ekonomi yang cukup besar untuk dimanfaatkan. Kolong Dam-3 Pemali merupakan salah satu kolong di Kabupaten Bangka yang sudah dimanfaatkan sebagai sumber air baku PDAM Tirta Bangka dan sumber air untuk keperluan balai benih ikan sentral (BBIS) Bangka Belitung. Pemanfaatan sumber air tersebut belum didasari pada prinsip nilai ekonomi air (NEA) (Sabri, 2008).

\section{Pemanfaatan Potensi Lingkungan}

Untuk pemanfaatan kolong yang berwawasan lingkungan, maka tindakan utama yang harus dilakukan adalah menghentikan sumber pencemar. Kemudian melakukan kegiatan reklamasi kolong dengan cara melakukan penghijauan. Untuk kegiatan ekowisata, yaitu dilengkapi dengan sarana dan prasarana. Sarana dan prasarana ekowisata, antara lain perahu kano, sepeda air, jet ski, dan lain-lain, sehingga kolongkolong tersebut ramai dikunjungi orang sebagai objek rekreasi. Untuk budidaya ikan terhadap kolong yang telah berusia 20 tahun yang tidak tercemar lagi oleh limbah bekas tambang timah dan budidaya eceng gondok. Eceng gondok dimanfaatkan sebagai bahan pembuatan tas. Karena eceng gondok ditanam di kolong bekas penambangan timah, eceng gondok mengandung briket yang disebut dengan eceng gondok briket sehingga dapat menghasilkan tas yang berkualitas, dan usaha ini terus dikembangkan di Kabupaten Bangka.

\section{Kesimpulan}

Industri pertambangan di Kabupaten Bangka, Provinsi Bangka Belitung telah memberikan sumbangan penting bagi pengembangan ekonomi masyarakat di daerah tersebut. Meskipun demikian muncul beberapa dampak negatif yang mengakibatkan terdegradasinya daya dukung lingkungan sehingga perlu perbaikan secara mendasar. Salah satu potensi ke arah tersebut adalah dengan memanfaatkan potensi bekas kolong tambang timah yang selama ini terbengkalai. Padahal kolong bekas pertambangan timah dapat menjadi cadangan air masyarakat setempat. Pemulihan lingkungan juga dapat dilakukan dengan penanaman tumbuhantumbuhan tertentu yang cocok dengan lingkungan setempat.

$$
\text { Usaha perbaikan lingkungan }
$$
bukanlah semata-mata pekerjaan jangka pendek untuk keperluan ekonomi yang sesaat semata, tetapi juga untuk keperluan jangka panjang. Kalau boleh usaha tersebut diarahkan pada pengembangan bidang ekonomi baru yang bisa menjadi sumber alternative bagi ekonomi masyarakat setempat. Dalam kaitan ini, semua pihak 
harus memiliki tanggungjawab agar tidak hanya mengeksploitasi sumberdaya alamnya saja, tetapi juga memulihkannya semula agar bisa dinikmati oleh generasi mendatang.

\section{DAFTAR PUSTAKA}

Biro Pusat Statistik dan Badan Perencanaan Pembangunan Daerah Pulau Bangka, 2010, Bangka Dalam Angka, 2010, BAPPEDA Tingkat II Pulau Bangka, Sungailiat.

PT.Timah Tbk. 2000. Studi Pemanfaatan Lahan Kolong Pasca Penambangan Timah.

Suparmoko, M. 1988. Ekonomi Pembangunan. Liberty : Yogyakarta.
Rachman Wiriosudarmo. 1997. Kerangka Acuan Pembangunan BerkelanjutanSektor Pertambangan dan Energi. Yayasan ECOMINE Nusa Lestari.

Henny, Cynthia. 2009. Karakteristik Limnologis Kolong Bekas Tambang Timah di Pulau Bangka. Vol: XVI (2), hal: 119-131.

Suparmoko, M. dan Ratnaningsih, M. 2011. Ekonomi Lingkungan. BPFE: Yogyakarta.

Peraturan Daerah Nomor 26 Tahun 2011 tentang Pengelolaan dan Pemanfaatan Kolong.

Sabri, Fadillah. 2008. Nilai Ekonomi Air Kolong DAM-3 Pemali Kabupaten Bangka . Tesis. Penerbit Universitas Gadjah Mada, Yogyakarta. 